\title{
Effect of zinc solubilizing bacteria on growth promotion and zinc nutrition of rice
}

\author{
S.K. Vaid ${ }^{1 *}$, B. Kumar ${ }^{2}$, A. Sharma ${ }^{1}$, A.K. Shukla ${ }^{3}$ and P.C. Srivastava ${ }^{4}$ \\ ${ }^{1}$ Department of Agriculture, Lovely Professional University. Phagwara-144411 Punjab. India. *Corresponding \\ author:sachinsbaba@yahoo.com \\ ${ }^{2}$ Department of Environmental Science, Govind Ballabh Pant University of Agriculture and Technology, \\ Pantnagar-263145, India. \\ ${ }^{3}$ Indian Institute of Soil Science, Berasia Road, Bhopal-462038, India. \\ ${ }^{4}$ Department of Soil Science, Govind Ballabh Pant University of Agriculture and Technology, \\ Pantnagar-263145, India.
}

\begin{abstract}
A comparison study between the isolated indigenous bacteria and chemical $\mathrm{Zn}$ fertilizer $\left(\mathrm{ZnSO}_{4} .7 \mathrm{H}_{2} \mathrm{O}\right)$ was conducted to evaluate their potential to augment $\mathrm{Zn}$ nutrition of $\mathrm{Zn}$ responsive (NDR 359) and $\mathrm{Zn}$ non responsive (PD 16) varieties of rice under the green house. Three bacterial strains namely; $\mathrm{BC}, \mathrm{AX}$ and $\mathrm{AB}$ isolated from a $\mathrm{Zn}$-deficient rice-wheat field belonging to the genera Burkholderia and Acinetobacter were investigated for the growth promotion and $\mathrm{Zn}$ uptake in rice plants. The plant growth promotory properties such as $\mathrm{Zn}$ solubilization and IAA production of the isolates was checked in a previous study. These three isolates when used individually or in combination were found effective in significantly increasing the mean dry matter yield/pot (12.9\%), productive tillers/plant (15.1\%), number of panicles/plant (13.3\%), number of grains/panicle $(12.8 \%)$, grain yield $(17.0 \%)$ and straw yield (12.4\%) over the control and $\mathrm{Zn}$ fertilizer treatment, respectively. Bacterial inoculations also significantly enhanced the total $\mathrm{Zn}$ uptake/pot (52.5\%) as well as grain methionine concentration (38.8\%). Effect of bacterial treatments on the bioavailability of $\mathrm{Zn}$ was assessed by estimating the levels of phytic acid in grains. A reduction of nearly $38.4 \%$ in phytate: $\mathrm{Zn}$ ratio in grains was observed under bacterial inoculations.
\end{abstract}

Keywords: Rice, PGPR, Zn uptake, Methionine, Phytic acid 


\section{Introduction}

India is considered to be one of the original centers of rice cultivation, covering 44 million hectares of land. The rice harvesting area in India is the largest in the world. In India, rice accounts $40 \%$ of the nation's food production and it is a staple food of around $65 \%$ total population. Rice-based production systems provide the main source of income and employment for more than 50 million households. The rice production in India was 15.57 thousand tons for the year 2011 (http:www.irri.org).

The main constraints in rice production in India include high rainfall/drought conditions, continuous use of traditional varieties due to non availability of seeds of improved varieties or unawareness of the farmers about them, heavy infestation of weeds/pests, low soil fertility, imbalanced use of fertilizers and many more which altogether result in low rice production. Among these factors, low soil fertility is the most important factor which not only seriously affects the rice production but reduce the quality of the rice. Chaudhary et al. (2007) reported Zn deficiency as a key factor in determining the rice production in several parts of India. According to Singh (2009), 48\% soils in India are afflicted with $\mathrm{Zn}$ deficiency. In rice, $\mathrm{Zn}$ deficiency causes multiple symptoms that usually appear 2 to 3 weeks after transplanting (WAT) rice seedlings; leaves develop brown blotches and streaks that may fuse to cover older leaves entirely, plants remain stunted and in severe cases may die also, while those which recover show substantial delay in maturity and reduction in yield (Yoshida and Tanaka, 1969; Van Breemen and Castro, 1980; Neue and Lantin, 1994). In countries, like India where the diet is mainly cereal based, consumption of rice grown on these low $\mathrm{Zn}$ soils often cause the adequate intake of $\mathrm{Zn}$ in young children and population. The aftermath of low $\mathrm{Zn}$ consumption is the impairment in growth and immune functions leading to infectious diseases such as diarrhoea and pneumonia in the developing world (Volkmar and Bremer, 1998; Graham, 2008). Brain function and development is also significantly affected by $\mathrm{Zn}$ deficiency, mainly in newborns (Benton, 2008). Zinc deficiency was found to be one major reason for child death worldwide, and was responsible for nearly 450,000 deaths in children less than 5 years of age (Black et al., 2008; Cakmak, 2010). According to a report published in 2002 by WHO, Zn deficiency is considered as the fifth most important risk factor responsible for illness and death in the developing world. In human body, $\mathrm{Zn}$ plays an important role in maintaining the structure and function of large number of macromolecules and is also found responsible for controlling over 300 enzymatic reactions (Tapiero and Tew, 2003). Graham (2008) stated that Zinc deficiency is the highest priority among micronutrients for agriculture to address.

The use of chemical fertilizers and manures, to enhance soil fertility and crop productivity has often negatively affected the complex biogeochemical cycles (Perrott et al., 1992; Steinshamn et al., 2004). Continuous application of fertilizers as well as their low use efficiency has caused leaching and runoff of nutrients, especially $\mathrm{N}$ and $\mathrm{P}$ leading to environmental degradation (Tilman, 1998; Gyaneshwar et al., 2002). On the other hand, 
high cost associated with the application of Zn fertilizers in order to correct Zn deficiency places considerable burden on resource poor farmers (Wissuwa et al., 2006). One of the possible ways to increase crop productivity as well as food quality without creating the environmental issues is by the use of plant growth promotory rhizobacteria (PGPR). There are several studies where PGPR were proved as good alternative of chemicals for increasing the plant growth and yield and help reduction in the use of hazardous agro-chemicals. The PGPR were capable of colonizing the rhizosphere, root surface and internal tissues in plants. The main microbial mechanisms by which PGPR improved plant growth include N-fixation, inorganic $\mathrm{P}$ solubilisation, siderophore production, phytohormone synthesis and by controlling plant pathogens (Lugtenberg and Kamilova, 2009). Different plant growth promoting bacteria including free living and associative such as Azospirillum, Azotobacter, Bacillus and Pseudomonas have been used in agricultural systems as biofertilizers for their beneficial effects on plant growth (Tilak et al 1982). Tran Van et al. (2000) has reported the beneficial effects of Burkholderia vietnamiensis inoculation on rice plants. Recently, Sharma et al. (2014) have also reported the positive inoculation effect of PGPR's isolated from rice rhizosphere on growth promotion of different rice genotypes. Ogut et al. (2013) have observed the $\mathrm{P}$ solubilisation potential of Acinetobacter strains. They inoculated wheat plants with Acinetobacter sp. WR922 and found increased plant $\mathrm{P}$ nutrition as well as dry matter accumulation.
Most crops are found deficient in certain essential amino acids that cannot be synthesized de novo by humans. In nonruminants even if one essential amino acid is present in insufficient amounts, the remaining amino acids would be broken down, leading to nitrogen loss and poor growth (Shewry, 2006). Zhu et al. (2007) had reported that $50 \%$ of the world's population relies on cereals or legumes as a staple diet so strategies must be developed to enhance the content of essential amino acids in order to prevent deficiency diseases in the population. Considering this fact in mind we have checked the effect of bacterial inoculations on methionine concentration in rice grains.

Phytic acid is myo-inositol 1,2,3,4,5,6-hexakisphosphate (InsP6), and is a known form of stored phosphorus (P) in most seeds and cereal grains. Approximately $70 \%$ of total phosphorus in seeds coexists with phytic acid and its content typically accounts for $1 \%$ or more of seed dry weight (Lott, 1984). Phytic acid has a strong ability to chelate multivalent metal ions, specially zinc, calcium and iron. The binding can result in very insoluble salts with poor bioavailability of minerals (Rhou and Erdman, 1995). InsP6 induced low nutrient uptake poses a major public health problem in the form of zinc and iron deficiency, in populations that live mainly on grains and legumes.

In this study, three $\mathrm{Zn}$ solubilising bacteria previously isolated from the rhizosphere of rice plants growing in $\mathrm{Zn}$ deficient soil were evaluated singly as well as in combination for growth promotion and $\mathrm{Zn}$ uptake of two rice varieties having varying $\mathrm{Zn}$ response under greenhouse conditions. To explore the effect of bacterial inoculations on $\mathrm{Zn}$ bioavailability, 
phytic acid concentration as well as phytic acid: $\mathrm{Zn}$ ratio was also examined.

\section{Material and Methods}

\subsection{Bacterial culture}

Plant growth promotory bacteria used in this study were three bacterial strains that have been previously tried on wheat (Vaid et al 2013). Based on partial 16S rRNA sequencing, these bacterial strains were identified as belonging to the genera Burkholderia and Acinetobacter. These three bacterial cultures are submitted in Genbank (NCBI) and accession numbers are obtained. All the three bacterial isolates were checked previously for their PGPR properties such as $\mathrm{Zn}$ and P-solubilization as well as for siderophore and IAA production (Vaid et al 2013).

\subsection{Experimental design and conditions}

A pot experiment was carried out in the experimental area of Department of Microbiology, G. B Pant University of Agriculture \& Technology, Pantnagar India. Surface $(0-15 \mathrm{~cm})$ soil used in this experiment was a $\mathrm{Zn}$ deficient loam belonging to soil order mollisol which was collected from the Norman E. Borlaug Crop research centre of the university. Since the critical limit of $\mathrm{Zn}$ in mollisols in terms of DTPA ( $\mathrm{pH} 7.3$ ) extractable $\mathrm{Zn}$ has been reported as $1.24 \mathrm{mg} \mathrm{Zn} \mathrm{kg}{ }^{-1}$ soil (Srivastava and Gangwar, 1990) and the content of DTPA (pH 7.3) extractable Zn was $0.42 \mathrm{mg}$ $\mathrm{Zn} \mathrm{kg}^{-1}$ soil, therefore, a prefix 'deficient' was used before loam. The total $\mathrm{Zn}$ content of soil used in pot experiment was $245 \mathrm{mg} \mathrm{Zn} \mathrm{kg}{ }^{-1}$ soil. The physico-chemical characteristics of the experimental soil are shown in (Table 1). For pot experiment, air dried soil was passed through $2.0 \mathrm{~mm}$ sieve before use. Plastic pots used in the experiment were filled with $4 \mathrm{~kg}$ soil, watered and left for 1 to 2 days for equilibration. A basal dose of $33.48 \mathrm{mg} \mathrm{N}$ as urea, $11.71 \mathrm{mg} \mathrm{P}$ and $14.82 \mathrm{mg} \mathrm{K}$ through potassium dihydrogen orthophosphate and potassium chloride $\mathrm{kg}^{-1}$ soil was uniformly applied to each pot. There were total nine treatments and each treatment was replicated thrice. The treatments were: control, basal application of $\mathrm{Zn}$ at the rate of $2.5 \mathrm{mg}$ $\mathrm{Zn}$ as $\mathrm{ZnSO}_{4} \cdot 7 \mathrm{H}_{2} \mathrm{O} \mathrm{kg}{ }^{-1}$ soil, bacterial cultures Burkholderia sp. SG1 (BC), Acinetobacter sp. SG2 (AX), Acinetobacter sp. SG3 (AB) and their combinations $(\mathrm{BC}+\mathrm{AX}),(\mathrm{BC}+\mathrm{AB}),(\mathrm{AX}+\mathrm{AB})$ and $(\mathrm{BC}+\mathrm{AX}+\mathrm{AB})$. The control and basal application of $2.5 \mathrm{mg} \mathrm{Zn} \mathrm{kg} \mathrm{Zn}^{-1}$ soil did not receive any bacterial treatment. The experimental design used was a factorial complete randomized design (CRD) with two factors.

Bacterial inocula for plant inoculation was prepared by growing pure cultures of $\mathrm{Zn}$ solubilising bacteria AX in Nutrient broth, BC in King's B medium and AB in Tryptic soy broth. The inoculated broths were placed on a rotary shaker at $100 \mathrm{rpm}$ and $30^{\circ} \mathrm{C}$ for 24 to $48 \mathrm{~h}$. The final concentration of the bacterial suspension was enumerated by plate count and adjusted to $10^{8} \mathrm{Cfu} / \mathrm{ml}$. The seedlings of two rice varieties PD 16 ( $\mathrm{Zn}$ non-responsive) and NDR 359 ( $\mathrm{Zn}$ responsive) were separately raised in the experimental soil. The roots of rice seedlings (21 days old) were thoroughly washed with tap water, surface sterilized in $2 \%$ $\mathrm{NaOCl}$ for $15 \mathrm{~min}$ and finally rinsed with sterile distilled $\mathrm{H}_{2} \mathrm{O}$ and were inoculated by soaking them overnight in different bacterial inocula 
maintained at $10^{8} \mathrm{cfu} / \mathrm{ml}$. Six seedlings were transplanted per pot (two plants per hill) and grown until maturity to get final yield. Two top dressings of urea were done at 22 and $60 \mathrm{~d}$ after transplanting of rice. Before harvesting, the data on productive tillers/plant, total number of panicles/plant and number of grains/panicle were recorded at maturity.

Table 1: Some physical and chemical properties of soil used for pot experiment.

\begin{tabular}{|c|c|}
\hline Property & Values \\
\hline Texture & Loam (Mollisol) \\
\hline Organic carbon $(\%)$ & 1.03 \\
\hline Sand $(\%)$ & 36 \\
\hline Silt $(\%)$ & 40 \\
\hline Clay $(\%)$ & 24 \\
\hline $\mathrm{pH}(1: 2)$ soil:water suspension & 7.0 \\
\hline Electrical conductance $\left(\mathrm{dS} \mathrm{m}^{-1}\right)$ & 0.278 \\
\hline DTPA (pH 7.3) extr. Zn (mg kg $\left.{ }^{-1}\right)$ & 0.42 \\
\hline DTPA (pH 7.3) extr. $\mathrm{Cu}\left(\mathrm{mg} \mathrm{kg}^{-1}\right)$ & 1.24 \\
\hline DTPA (pH 7.3) extr. Fe (mg kg$\left.{ }^{-1}\right)$ & 25.3 \\
\hline DTPA (pH 7.3) extr. $\mathrm{Mn}\left(\mathrm{mg} \mathrm{kg}^{-1}\right)$ & 5.79 \\
\hline
\end{tabular}

\subsection{Harvesting of plants}

All the plants in the pots were harvested close to soil surface at maturity and washed thoroughly with tap water followed by washing with $0.1 \mathrm{~N} \mathrm{HCl}$ and then with distilled water. After initial air drying, plant samples were kept in paper bags, dried at $60^{\circ} \mathrm{C}$ in an electric oven for $48 \mathrm{~h}$ and weighed to determine the dry matter yield. The thousand grain weight, grain and straw yields were also recorded. After harvesting of rice, the soil from each pot was also collected to analyse the effect of different bacterial treatments on the amount of DTPA extractable Zn (Lindsay and Norvell 1978) using atomic absorption spectrophotometer (GBC Avanta M).

\subsection{Zn analysis}

For $\mathrm{Zn}$ analysis, the grains and straw samples were finely ground and $1.0 \mathrm{~g}$ sample was digested in $10 \mathrm{ml}$ diacid mixture $\left(\mathrm{HNO}_{3}: \mathrm{HClO}_{4}\right.$, $4: 1 \mathrm{v} / \mathrm{v}$ ) and diluted to $50 \mathrm{~mL}$ using distilled water. Zinc was analyzed by atomic absorption spectrophotometry (GBC Avanta M). Methionine and phytic acid concentration was estimated spectrophotometrically in grains by the methods of Latta and Eskin. (1980) and Horn et al. (1946), respectively.

\subsection{Statistical analysis}

The data were subjected to the analysis of variance using a factorial completely randomized 
design using an STPR software designed at the Department of Mathematics, Statistics and Computer Science, CBSH, G.B. Pant University of Agriculture and Technology, Pantnagar, India. The significant differences among the treatments were calculated at $5 \%$ probability levels $(p \leq 0.05)$ (Snedecor and Cochran, 1967).

\section{Results}

\subsection{Bacterial isolates}

The bacterial isolates described as Zn solubilizers were identified as strains of Burkholderia sp. SG1 (BC), Acinetobacter sp. SG2 (AX) and Acinetobacter sp. SG3 (AB) according to $16 \mathrm{~S}$ rDNA sequencing. These strains were submitted to NCBI and the assigned accession numbers were: HQ844430, KC202811 and HQ844431, respectively. The $\mathrm{Zn}$ solubilizing capacity of $\mathrm{BC}, \mathrm{AX}$ and $\mathrm{AB}$ in broth assay as well as on plate assay was checked in a previous study by Vaid et al. (2013).

\subsection{Effect of bacterial inoculation on} Growth and yield attributing characters of rice plants

The data on the effect of different treatments on growth and yield attributing characters of both the rice varieties are presented in (Table 2). Rice variety NDR 359 ( $\mathrm{Zn}$ responsive) showed higher total number of panicles/pot and 1000 grain weight as compared to $\mathrm{Zn}$ non-responsive variety (PD 16). The two varieties were found statistically similar to each other with respect to number of productive tillers/plant.

The effect of different treatments averaged over the rice varieties revealed that all the treatments significantly increased the dry matter yield/pot over the control (Table 2). The maximum dry matter yield/pot was observed under the treatment $\mathrm{BC}+\mathrm{AX}$ with an increase of 12.9 and $7.3 \%$ over the control and $\mathrm{Zn}$ fertilizer application, respectively. Statistically the treatment $\mathrm{BC}+\mathrm{AX}$ was found at par with treatments $\mathrm{AX}$ and $\mathrm{BC}+\mathrm{AX}+\mathrm{AB}$. As regards the number of productive tillers per plant, the best treatments observed were $\mathrm{BC}+\mathrm{AB}$ and $\mathrm{AX}+\mathrm{AB}$. These treatments increased the number of productive tillers per plant by $15.1 \%$ over the control and $\mathrm{Zn}$ fertilizer application, respectively. Application of $\mathrm{Zn}$ at the rate of $2.5 \mathrm{mg} \mathrm{kg}^{-1}$ soil as well as the bacterial treatments $\mathrm{BC}, \mathrm{AB}$ and $\mathrm{BC}+\mathrm{AX}$ could only maintained the number of productive tillers per plant equal to the control. All the treatments except $\mathrm{AX}+\mathrm{AB}$ were found statistically ineffective in increasing the total number of panicles per pot as compared to the control. The increase recorded in the number of panicles per pot under the treatment $\mathrm{AX}+\mathrm{AB}$ was 13.3 and $18.5 \%$ over the control and $\mathrm{Zn}$ fertilizer application, respectively. The number of grains per panicle were found maximum in plants which received $\mathrm{BC}$ treatment and the increase recorded was 12.8 and $7.4 \%$ over the control and $\mathrm{Zn}$ fertilizer application, respectively. The treatments $\mathrm{AX}, \mathrm{BC}+\mathrm{AX}$ and $\mathrm{AX}+\mathrm{AB}$ were found statistically at par with treatment $\mathrm{BC}$. With respect to 1000 grain weight, none of the bacterial treatment or application of $\mathrm{Zn}$ fertilizer were found to be statistically significant over the control.

The interaction effect of treatment $x$ variety significantly influenced all the growth and yield attributing characters except 1000 grain weight (Table 2). In $\mathrm{PD} 16$, treatment $\mathrm{BC}+\mathrm{AX}+\mathrm{AB}$ increased the dry matter yield per pot maximally over the control; the magnitude of increase 
recorded was 21.3 and $15.8 \%$ over the control and $\mathrm{Zn}$ fertilizer application, respectively. Statistically, the treatment $\mathrm{BC}+\mathrm{AX}$ and $\mathrm{BC}+\mathrm{AX}+\mathrm{AB}$ were found similar to each other. In NDR 359, all the treatments except $\mathrm{BC}+\mathrm{AB}$ and $\mathrm{BC}+\mathrm{AX}+\mathrm{AB}$ significantly increased the dry matter yield per pot. The maximum dry matter yield per pot was observed for plants which received the treatment $\mathrm{AX}$ and the increase recorded was 9.0 and $3.3 \%$ over the control and $\mathrm{Zn}$ fertilizer application, respectively. In PD 16, none of the treatment was found statistically significantly effective in increasing the number of productive tillers per plant. In the case of NDR 359, the treatments $\mathrm{AX}, \mathrm{BC}+\mathrm{AX}, \mathrm{BC}+\mathrm{AB}$ and $\mathrm{AX}+\mathrm{AB}$ significantly increased the number of productive tillers per plant over the control and were found statistically similar to each other. Among these treatments, the maximum increase (30.4\%) over the control and $\mathrm{Zn}$ fertilizer application was recorded under the treatment $\mathrm{AX}+\mathrm{AB}$. In $\mathrm{PD} 16$, all the treatments were found statistically ineffective in enhancing the total number of panicles per pot over the control. On the other hand in NDR 359, total number of panicles per pot was significantly increased under the treatments $\mathrm{BC}, \mathrm{BC}+\mathrm{AB}$ and $\mathrm{AX}+\mathrm{AB}$. However, treatment $\mathrm{AX}+\mathrm{AB}$ maximally increased the total number of panicles per pot and this increase was $30.4 \%$ over the control and Zn fertilizer application, respectively. In PD 16, number of grains per panicle was found higher under treatments $\mathrm{BC}$ and $\mathrm{AX}+\mathrm{AB}$. Statistically, treatments $\mathrm{BC}$ and $\mathrm{AX}+\mathrm{AB}$ were found similar to each other. Among these maximum increase in number of grains per panicle was observed under treatment $\mathrm{BC}$ and the increase was 13.2 and $13.0 \%$ over the control and $\mathrm{Zn}$ fertilizer application, respectively. In NDR 359, plants received the treatment $\mathrm{AX}$ produced the highest number of grains per panicle. The increase in number of grains per panicle recorded under treatment AX was 21.4 and $10.2 \%$ over the control and $\mathrm{Zn}$ fertilizer application, respectively. The treatment $\mathrm{BC}+\mathrm{AX}$ was found statistically similar to treatment AX.

Table 2: Growth response of rice plants inoculated with $\mathrm{Zn}$ solubilizing bacteria.

\begin{tabular}{|c|c|c|c|c|c|c|c|c|c|c|c|c|c|c|c|}
\hline \multirow{2}{*}{ Treatments } & \multicolumn{3}{|c|}{$\begin{array}{l}\text { Dry matter yield/pot } \\
(\mathrm{g})\end{array}$} & \multicolumn{3}{|c|}{$\begin{array}{l}\text { Productive } \\
\text { tillers/plant }\end{array}$} & \multicolumn{3}{|c|}{$\begin{array}{l}\text { Total no. of } \\
\text { panicles/pot }\end{array}$} & \multicolumn{3}{|c|}{ No. of grains/panicle } & \multicolumn{3}{|c|}{$\begin{array}{l}1000 \text { grain weight } \\
\text { (g) }\end{array}$} \\
\hline & PD16 & NDR 359 & Mean & PD16 & $\begin{array}{c}\text { NDR } \\
359\end{array}$ & Mean & PD16 & $\begin{array}{c}\text { NDR } \\
359 \\
\end{array}$ & Mean & PD16 & $\begin{array}{c}\text { NDR } \\
359\end{array}$ & Mean & PD16 & $\begin{array}{c}\text { NDR } \\
359\end{array}$ & Mean \\
\hline Control & $59.1^{\mathrm{a}}$ & $59.9^{\mathrm{ab}}$ & 59.5 & $7.67^{\mathrm{a}}$ & $7.67^{\mathrm{a}}$ & 7.67 & $7.33^{\mathrm{abc}}$ & $7.67^{\text {bcd }}$ & 7.50 & $138.5^{\mathrm{abc}}$ & $129.4^{\mathrm{a}}$ & 133.9 & $25.1^{\mathrm{a}}$ & $26.3^{\text {abcd }}$ & 25.7 \\
\hline $\begin{array}{l}2.5 \mathrm{mg} \mathrm{Zn} / \mathrm{kg} \\
\text { soil }\end{array}$ & $61.9^{\mathrm{abcd}}$ & $63.2^{\text {cdef }}$ & 62.6 & $7.67^{\mathrm{a}}$ & $7.67^{\mathrm{a}}$ & 7.67 & $6.67^{\mathrm{ab}}$ & $7.67^{\mathrm{bcd}}$ & 7.17 & $138.8^{\mathrm{abc}}$ & $142.5^{\text {bed }}$ & 140.7 & $25.4^{\mathrm{ab}}$ & $27.3^{\mathrm{abcd}}$ & 26.4 \\
\hline BC & $64.7^{\text {defg }}$ & $63.4^{\text {edef }}$ & 64.1 & $8.33^{\mathrm{abc}}$ & $8.00^{\mathrm{ab}}$ & 8.17 & $7.33^{\mathrm{abc}}$ & $8.67^{\mathrm{de}}$ & 8.00 & $156.8^{\mathrm{e}}$ & $145.3^{\mathrm{cd}}$ & 151.1 & $25.2^{\mathrm{ab}}$ & $26.8^{\mathrm{abcd}}$ & 26.0 \\
\hline $\mathbf{A X}$ & $66.0^{\mathrm{fg}}$ & $65.3^{\mathrm{efg}}$ & 65.7 & $7.67^{\mathrm{a}}$ & $9.33^{\mathrm{cd}}$ & 8.50 & $7.33^{\text {abc }}$ & $8.00^{\text {cd }}$ & 7.67 & $139.9^{\mathrm{abc}}$ & $157.1^{e}$ & 148.5 & $25.1^{\mathrm{a}}$ & $28.7^{\mathrm{d}}$ & 26.9 \\
\hline$A B$ & $64.4^{\text {cdefg }}$ & $63.2^{\text {bcdef }}$ & 63.8 & $8.67^{\mathrm{abc}}$ & $7.67^{\mathrm{a}}$ & 8.17 & $7.33^{\mathrm{abc}}$ & $7.67^{\text {bcd }}$ & 7.50 & $140.7^{\mathrm{abed}}$ & $143.7^{\mathrm{cd}}$ & 142.2 & $25.6^{\mathrm{abc}}$ & $28.0^{\mathrm{cd}}$ & 26.8 \\
\hline $\mathbf{B C}+\mathbf{A X}$ & $69.6^{\text {hi }}$ & $64.7^{\mathrm{defg}}$ & 67.2 & $7.67^{\mathrm{a}}$ & $9.00^{\text {bcd }}$ & 8.33 & $6.33^{\mathrm{a}}$ & $8.00^{\mathrm{cd}}$ & 7.17 & $144.7^{\text {ed }}$ & $148.4^{\text {cde }}$ & 146.6 & $25.4^{\mathrm{ab}}$ & $28.0^{\mathrm{cd}}$ & 26.7 \\
\hline $\mathbf{B C}+\mathbf{A B}$ & $66.8^{\text {gh }}$ & $62.2^{\text {abcde }}$ & 64.5 & $8.67^{\mathrm{abc}}$ & $9.00^{\text {bcd }}$ & 8.83 & $7.00^{\mathrm{abc}}$ & $9.33^{\mathrm{ef}}$ & 8.17 & $143.7^{\mathrm{cd}}$ & $137.7^{\mathrm{abc}}$ & 140.7 & $25.7^{\mathrm{abc}}$ & $27.7^{\text {bed }}$ & 26.7 \\
\hline $\mathrm{AX}+\mathbf{A B}$ & $61.0^{\mathrm{abc}}$ & $63.3^{\text {cdef }}$ & 62.2 & $7.67^{\mathrm{a}}$ & $10.00^{\mathrm{d}}$ & 8.83 & $7.00^{\mathrm{abc}}$ & $10.00^{f}$ & 8.50 & $152.3^{\mathrm{de}}$ & $138.0^{\mathrm{abc}}$ & 145.2 & $25.1^{\mathrm{a}}$ & $26.5^{\text {abcd }}$ & 25.8 \\
\hline $\mathbf{B C}+\mathbf{A X}+\mathbf{A B}$ & $71.7^{\mathrm{i}}$ & $61.5^{\mathrm{abcd}}$ & 66.6 & $8.67^{\mathrm{abc}}$ & $8.6^{\mathrm{abc}}$ & 8.67 & $7.33^{\text {abc }}$ & $7.67^{\mathrm{bcd}}$ & 7.50 & $142.4^{\mathrm{bcd}}$ & $131.8^{\mathrm{ab}}$ & 137.1 & $25.4^{\mathrm{ab}}$ & $28.7^{\mathrm{d}}$ & 27.0 \\
\hline Mean & 65.0 & 63.0 & 64.01 & 8.07 & 8.56 & 8.31 & 7.07 & 8.30 & 7.69 & 144.2 & 141.6 & 142.9 & 25.3 & 27.6 & 26.4 \\
\hline
\end{tabular}

Pair of treatments that are not significantly different from one another share the same letters checked by the Duncan's test at $5 \%$ probability level. 


\subsection{Effect of bacterial inoculation on Grain and straw yield of rice plants}

Rice variety PD 16 showed higher grain yield while straw yield was found higher for NDR 359 (Table 3).

The effect of different treatments averaged over the rice varieties revealed that all the treatments significantly increased the grain and straw yield per pot (Table 3 ). Grain yield was found maximum under the treatment AX which was 17.0 and $5.8 \%$ higher over the control and $\mathrm{Zn}$ fertilizer application, respectively. Statistically, the treatments AX and $\mathrm{BC}$ were found similar to each other. On the other hand, the maximum straw yield was observed under the treatment $\mathrm{BC}+\mathrm{AX}+\mathrm{AB}$ and the increase recorded was 12.4 and $4.8 \%$ over the control and $\mathrm{Zn}$ fertilizer application, respectively.

Table 3: Effect of different treatments on grain and straw yields of two rice varieties.

\begin{tabular}{|c|c|c|c|c|c|c|}
\hline \multirow{2}{*}{ Treatments } & \multicolumn{3}{|c|}{ Grain yield $\left(\mathrm{g} \mathrm{pot}^{-1}\right)$} & \multicolumn{3}{|c|}{ Straw Yield $\left(\mathrm{g} \mathrm{pot}^{-1}\right)$} \\
\hline & PD 16 & NDR 359 & Mean & PD 16 & NDR 359 & Mean \\
\hline Control & $19.4^{\mathrm{b}}$ & $18.3^{\mathrm{a}}$ & 18.8 & $41.0^{\mathrm{a}}$ & $41.3^{\mathrm{ab}}$ & 41.2 \\
\hline $2.5 \mathrm{mg} \mathrm{Zn} / \mathrm{kg}$ soil & $20.2^{\mathrm{de}}$ & $21.4^{\mathrm{fg}}$ & 20.8 & $46.6^{\mathrm{h}}$ & $41.8^{\mathrm{abcd}}$ & 44.2 \\
\hline BC & $22.2^{\mathrm{h}}$ & $21.7^{\mathrm{gh}}$ & 21.9 & $42.5^{\mathrm{def}}$ & $41.7^{\mathrm{abcd}}$ & 42.1 \\
\hline $\mathbf{A X}$ & $20.1^{\text {cde }}$ & $23.8^{\mathrm{j}}$ & 22.0 & $41.7^{\mathrm{abcd}}$ & $41.6^{\mathrm{abcd}}$ & 41.7 \\
\hline $\mathbf{A B}$ & $21.1^{\mathrm{f}}$ & $21.9^{\mathrm{gh}}$ & 21.5 & $43.3^{\mathrm{cf}}$ & $41.6^{\mathrm{abcd}}$ & 42.4 \\
\hline $\mathbf{B C}+\mathbf{A X}$ & $20.4^{\mathrm{e}}$ & $22.7^{\mathrm{i}}$ & 21.6 & $49.2^{\mathrm{i}}$ & $42.0^{\mathrm{abcd}}$ & 45.6 \\
\hline $\mathbf{B C}+\mathrm{AB}$ & $21.5^{\mathrm{fg}}$ & $19.8^{\mathrm{bcd}}$ & 20.6 & $45.3^{\mathrm{g}}$ & $42.4^{\mathrm{cde}}$ & 43.8 \\
\hline $\mathbf{A X}+\mathbf{A B}$ & $19.6^{\mathrm{bc}}$ & $21.0^{\mathrm{f}}$ & 20.3 & $43.4^{\mathrm{f}}$ & $42.3^{\mathrm{bcd}}$ & 42.9 \\
\hline $\mathbf{B C}+\mathbf{A X}+\mathbf{A B}$ & $20.5^{\mathrm{e}}$ & $20.2^{\text {cde }}$ & 20.3 & $51.2^{\mathrm{j}}$ & $41.4^{\mathrm{abc}}$ & 46.3 \\
\hline Mean & 20.5 & 21.2 & 20.9 & 44.9 & 41.8 & 43.4 \\
\hline
\end{tabular}

Pair of treatments that are not significantly different from one another share the same letters checked by the Duncan's test at $5 \%$ probability level.

The interaction effect of treatment $\times$ variety significantly influenced the grain and straw yield of both of the rice varieties (Table 3). In PD 16, all the treatments except $\mathrm{AX}+\mathrm{AB}$ significantly enhanced the grain yield per pot and highest value $(22.2 \mathrm{~g})$ was observed under the treatment $\mathrm{BC}$. The increase in grain yield recorded under treatment $\mathrm{BC}$ was 14.4 and $9.9 \%$ over the control and $\mathrm{Zn}$ fertilizer application, respectively. In NDR 359, plants receiving the 
treatment AX showed the maximum grain yield per pot with percent increase of 30.1 and 11.2 over the control and $\mathrm{Zn}$ fertilizer application, respectively. As regards the straw yield, in PD 16 all the treatments except AX were found effective in enhancing the straw yield per pot. Among all the treatments, the best treatment observed was $\mathrm{BC}+\mathrm{AX}+\mathrm{AB}$ which increased the straw yield per pot by 24.9 and $9.9 \%$ over the control and $\mathrm{Zn}$ fertilizer application respectively. While in NDR 359, the increase in straw yield per pot was observed only under the treatments $\mathrm{BC}+\mathrm{AB}$ and $\mathrm{AX}+\mathrm{AB}$ and the rest all treatments only maintained the straw yield per pot equal to control. Application of $\mathrm{BC}+\mathrm{AB}$ increased the straw yield per pot by 2.7 and $1.4 \%$ over the control and $\mathrm{Zn}$ fertilizer application, respectively. The treatments $\mathrm{BC}+\mathrm{AB}$ and $\mathrm{AX}+\mathrm{AB}$ were also found statistically similar to each other.

\subsection{Effect of bacterial inoculation on $\mathrm{Zn}$ concentration in grains}

The mean $\mathrm{Zn}$ concentration in grains of two rice varieties did not differ significantly (Table 4).

The performance of different treatments averaged over the rice varieties showed that most of the treatments significantly increased the $\mathrm{Zn}$ concentration in grains (Table 4). The highest Zn concentration in grains was observed in plants received the treatment $\mathrm{BC}+\mathrm{AX}$ and the increase recorded was 56.9 and $41.6 \%$ over the control and $\mathrm{Zn}$ fertilizer application, respectively.

The interaction effect of treatment $x$ variety significantly influenced the $\mathrm{Zn}$ concentration in grains (Table 4). In PD 16 and NDR 359, the highest $\mathrm{Zn}$ concentration in grains was recorded under the treatment $\mathrm{BC}+\mathrm{AX}$. In PD 16, the percent increment in grain $\mathrm{Zn}$ concentration observed under $\mathrm{BC}+\mathrm{AX}$ was 50.5 and 34.2 over the control and $\mathrm{Zn}$ fertilizer application, respectively. While in NDR 359, the increase in grain $\mathrm{Zn}$ concentration recorded under $\mathrm{BC}+\mathrm{AX}$ was 66.7 and $49.5 \%$ over the control and $\mathrm{Zn}$ fertilizer application, respectively. In NDR 359, the treatments $\mathrm{AX}+\mathrm{AB}$ and $\mathrm{BC}+\mathrm{AX}+\mathrm{AB}$ were found statistically at par to treatment $\mathrm{BC}+\mathrm{AX}$.

\subsection{Effect of bacterial inoculation on $\mathrm{Zn}$ concentration in straw}

The statistical analysis revealed that $\mathrm{Zn}$ concentration in straw of NDR 359 was significantly higher as compared to that of PD 16 (Table 4).

The performance of different treatments averaged over the rice varieties showed that all the treatments significantly increased $\mathrm{Zn}$ concentration in straw (Table 4). Among all the treatments, the best treatment was $\mathrm{BC}+\mathrm{AB}$ which increased the straw $\mathrm{Zn}$ concentration by 42.7 and $14.4 \%$ over the control and $\mathrm{Zn}$ fertilizer application, respectively.

The interaction effect of treatment $x$ variety significantly influenced the $\mathrm{Zn}$ concentration in straw (Table 4). In PD 16, Zn concentration was the highest in straw of plants receiving $\mathrm{BC}+\mathrm{AB}$ treatment. The increase recorded under $\mathrm{BC}+\mathrm{AB}$ was 55.2 and $9.1 \%$ over the control and $\mathrm{Zn}$ fertilizer application, respectively. On the other hand in NDR 359, treatment BC was adjudged as the best treatment which increased the $\mathrm{Zn}$ concentration in straw by 36.0 and $25.9 \%$ over the control and $\mathrm{Zn}$ fertilizer application, respectively. Statistically, the values obtained under treatments $\mathrm{BC}+\mathrm{AX}$ and $\mathrm{BC}+\mathrm{AB}$ were found at par with the value obtained under treatment BC. 
Table 4: Effect of different treatments on $\mathrm{Zn}$ concentration in grain and straw of two rice varieties.

\begin{tabular}{|c|c|c|c|c|c|c|}
\hline \multirow{3}{*}{ Treatments } & \multicolumn{6}{|c|}{$\mathrm{Zn}$ concentration $\left(\mathrm{mg} \mathrm{kg}^{-1}\right)$} \\
\hline & \multicolumn{3}{|c|}{ Grain } & \multicolumn{3}{|c|}{ Straw } \\
\hline & PD 16 & NDR 359 & Mean & PD 16 & NDR 359 & Mean \\
\hline Control & $10.7^{\text {abcd }}$ & $9.6^{\mathrm{a}}$ & 10.2 & $20.1^{\mathrm{a}}$ & $21.1^{\mathrm{ab}}$ & 20.6 \\
\hline $2.5 \mathrm{mg} \mathrm{Zn} / \mathrm{kg}$ soil & $12.0^{\text {cde }}$ & $10.7^{\mathrm{abcd}}$ & 11.3 & $28.6^{\mathrm{i}}$ & $22.8^{\mathrm{bcd}}$ & 25.7 \\
\hline BC & $11.3^{\text {abcde }}$ & $10.3^{\mathrm{abc}}$ & 10.8 & $22.8^{\mathrm{bcd}}$ & $28.7^{\mathrm{i}}$ & 25.7 \\
\hline $\mathbf{A X}$ & $11.7^{\text {bcde }}$ & $10.1^{\mathrm{ab}}$ & 10.9 & $23.8^{\text {cdef }}$ & $21.8^{\mathrm{abc}}$ & 22.8 \\
\hline $\mathbf{A B}$ & $12.3^{\mathrm{de}}$ & $11.4^{\text {bede }}$ & 11.8 & $27.0^{\text {ghi }}$ & $23.2^{\mathrm{bcd}}$ & 25.1 \\
\hline $\mathbf{B C}+\mathbf{A X}$ & $16.1^{\mathrm{f}}$ & $16.0^{\mathrm{f}}$ & 16.0 & $27.3^{\text {ghi }}$ & $27.0^{\text {ghi }}$ & 27.2 \\
\hline $\mathbf{B C}+\mathbf{A B}$ & $12.1^{\mathrm{de}}$ & $12.6^{\mathrm{e}}$ & 12.3 & $31.2^{\mathrm{j}}$ & $27.6^{\mathrm{hi}}$ & 29.4 \\
\hline $\mathbf{A X}+\mathbf{A B}$ & $12.0^{\text {cde }}$ & $15.1^{\mathrm{f}}$ & 13.5 & $25.8^{\text {efgh }}$ & $23.5^{\text {bcde }}$ & 24.6 \\
\hline $\mathbf{B C}+\mathbf{A X}+\mathbf{A B}$ & $12.7^{\mathrm{e}}$ & $15.9^{\mathrm{f}}$ & 14.3 & $26.3^{\text {fghi }}$ & $24.9^{\operatorname{defg}}$ & 25.6 \\
\hline Mean & 12.3 & 12.4 & 12.3 & 25.9 & 24.5 & 25.2 \\
\hline
\end{tabular}

Pair of treatments that are not significantly different from one another share the same letters checked by the Duncan's test at 5\% probability level.

3.6. Effect of bacterial inoculation on $\mathrm{Zn}$ uptake in grains

Statistical analysis revealed that $\mathrm{Zn}$ uptake in grains of both the rice varieties was similar (Table 5).

The effect of different treatments averaged over the rice varieties revealed that all the treatments significantly increased $\mathrm{Zn}$ uptake in grains and it was the highest under the treatment $\mathrm{BC}+\mathrm{AX}$ (Table 5). The increase observed under this treatment was 79.9 and
$47.2 \%$ over the control and $\mathrm{Zn}$ fertilizer application, respectively.

The interaction effect of treatment $x$ variety significantly influenced the $\mathrm{Zn}$ uptake in grains per pot (Table 5). In PD 16 and NDR 359, the maximum $\mathrm{Zn}$ uptake in grains per pot was recorded under the treatment $\mathrm{BC}+\mathrm{AX}$. In $\mathrm{PD}$ 16 , the magnitude of increase recorded under $\mathrm{BC}+\mathrm{AX}$ was 57.6 and $35.8 \%$ over the control and $\mathrm{Zn}$ fertilizer application, respectively. However, this increase in NDR 359 was 106.4 and $59.2 \%$ over the control and $\mathrm{Zn}$ fertilizer application, respectively. 
Table 5: Effect of different treatments on $\mathrm{Zn}$ uptake in grain and straw of two rice varieties.

\begin{tabular}{|c|c|c|c|c|c|c|}
\hline \multirow{3}{*}{ Treatments } & \multicolumn{6}{|c|}{ Zn uptake $\left(\mu \mathrm{g} \mathrm{pot}^{-1}\right)$} \\
\hline & \multicolumn{3}{|c|}{ Grain } & \multicolumn{3}{|c|}{ Straw } \\
\hline & PD16 & NDR359 & Mean & PD16 & NDR359 & Mean \\
\hline Control & $207.8^{b}$ & $175.7^{\mathrm{a}}$ & 191.8 & $824.7^{\mathrm{a}}$ & $869.7^{\mathrm{ab}}$ & 847.2 \\
\hline $\begin{array}{c}2.5 \mathrm{mg} \mathrm{Zn} / \mathrm{kg} \\
\text { soil }\end{array}$ & $241.1^{\text {bcd }}$ & $227.9^{\text {bcd }}$ & 234.5 & $1332.7^{\mathrm{f}}$ & $952.7^{\mathrm{bc}}$ & 1142.7 \\
\hline $\mathrm{BC}$ & $249.1^{\mathrm{cd}}$ & $222.6^{b c}$ & 235.8 & $970.7^{\mathrm{bc}}$ & $1195.0^{\mathrm{e}}$ & 1082.8 \\
\hline $\mathbf{A X}$ & $234.1^{\mathrm{bcd}}$ & $241.3^{\mathrm{bcd}}$ & 237.7 & $994.3^{\mathrm{bc}}$ & $905.7^{\mathrm{abc}}$ & 950.0 \\
\hline AB & $259.4^{\mathrm{d}}$ & $249.1^{\mathrm{cd}}$ & 254.2 & $1168.7^{\mathrm{e}}$ & $963.3^{b c}$ & 1066.0 \\
\hline $\mathbf{B C}+\mathbf{A X}$ & $327.4^{\mathrm{e}}$ & $362.8^{\mathrm{f}}$ & 345.1 & $1345.7^{\mathrm{f}}$ & $1133.3^{\mathrm{de}}$ & 1239.5 \\
\hline $\mathbf{B C}+\mathrm{AB}$ & $259.2^{\mathrm{d}}$ & $248.4^{\mathrm{cd}}$ & 253.8 & $1412.0^{\mathrm{f}}$ & $1172.0^{\mathrm{e}}$ & 1292.0 \\
\hline $\mathbf{A X}+\mathbf{A B}$ & $234.7^{\text {bcd }}$ & $317.5^{\mathrm{e}}$ & 276.1 & $1119.3^{\mathrm{de}}$ & $992.3^{b c}$ & 1055.8 \\
\hline $\mathbf{B C}+\mathbf{A X}+\mathbf{A B}$ & $260.4^{\mathrm{d}}$ & $319.9^{\mathrm{e}}$ & 290.1 & $1345.7^{\mathrm{f}}$ & $1030.7^{\mathrm{cd}}$ & 1188.2 \\
\hline Mean & 252.6 & 262.8 & 257.7 & 1168.2 & 1023.9 & 1094.6 \\
\hline
\end{tabular}

Pair of treatments that are not significantly different from one another share the same letters checked by the Duncan's test at 5\% probability level.

\subsection{Effect of bacterial inoculation on $\mathrm{Zn}$ uptake in straw}

Zinc uptake in straw per pot was more in NDR 359 as compared to PD 16 variety (Table 5).

The effect of different treatments averaged over the rice varieties significantly influenced $\mathrm{Zn}$ uptake in straw (Table 5). All the treatments effectively enhanced $\mathrm{Zn}$ uptake in straw per pot over the control. The treatment which increased $\mathrm{Zn}$ uptake maximally was $\mathrm{BC}+\mathrm{AB}$ and the magnitude of increase was 52.5 and $13.1 \%$ over the control and $\mathrm{Zn}$ fertilizer application, respectively. Statistically treatment $\mathrm{BC}+\mathrm{AX}$ was found at par with treatment $\mathrm{BC}+\mathrm{AB}$.

The interaction between treatment and varieties significantly influenced the $\mathrm{Zn}$ uptake in straw (Table 5). In PD 16, all the treatments significantly increased $\mathrm{Zn}$ uptake in straw per pot over the control. The maximum $\mathrm{Zn}$ uptake in straw per pot was recorded under the treatment $\mathrm{BC}+\mathrm{AB}$ with an increase of $71.2 \%$ over the control. Application of $2.5 \mathrm{mg}$ $\mathrm{Zn} \mathrm{kg}{ }^{-1}$ soil, $\mathrm{BC}+\mathrm{AX}$ and $\mathrm{BC}+\mathrm{AX}+\mathrm{AB}$ were 
found statistically at par with the treatment $\mathrm{BC}+\mathrm{AB}$. In NDR 359, Zn uptake in straw per pot was the highest under the treatment $\mathrm{BC}$. The increase recorded under treatment $\mathrm{BC}$ was 37.4 and $25.4 \%$ over the control and $\mathrm{Zn}$ fertilizer application, respectively. The treatments $\mathrm{BC}$, $\mathrm{BC}+\mathrm{AX}$ and $\mathrm{BC}+\mathrm{AB}$ were found statistically similar to each other.

\subsection{Effect of bacterial inoculation on total Zn uptake}

Total Zn uptake/pot was found to be statistically similar for both rice varieties (Table 6). The performance of different treatments averaged over the rice varieties indicated that total $\mathrm{Zn}$ uptake per pot was significantly increased under all the treatments over the control (Table 6). The maximum total $\mathrm{Zn}$ uptake/pot occurred in plants receiving the treatment $\mathrm{BC}+\mathrm{AX}$ which was 52.5 and $15.0 \%$ higher over the control and $\mathrm{Zn}$ fertilizer application, respectively. Statistically, the treatment $\mathrm{BC}+\mathrm{AB}$ was found at par with treatment $\mathrm{BC}+\mathrm{AX}$.

The interaction effect of treatment $\times$ variety significantly influenced the total $\mathrm{Zn}$ uptake/ pot (Table 6). In PD 16, all the treatments enhanced total $\mathrm{Zn}$ uptake per pot over the control. The highest total $\mathrm{Zn}$ uptake was recorded under the treatment $\mathrm{BC}+\mathrm{AX}$. The increase recorded under this treatment was $62.0 \%$ over the control. The values of total $\mathrm{Zn}$ uptake/pot under treatments $2.5 \mathrm{mg} \mathrm{Zn} \mathrm{kg}^{-1}$ soil, $\mathrm{BC}+\mathrm{AB}$ and $\mathrm{BC}+\mathrm{AX}+\mathrm{AB}$ were found statistically similar to treatment $\mathrm{BC}+\mathrm{AX}$. On the other hand, in NDR 359, the treatment $\mathrm{BC}+\mathrm{AX}$ increased total $\mathrm{Zn}$ uptake by $43.1 \%$ over the control. Total $\mathrm{Zn}$ uptake values observed under treatments $\mathrm{BC}$ and $\mathrm{BC}+\mathrm{AB}$ were statistically at par with the value obtained under treatment $\mathrm{BC}+\mathrm{AX}$.

Table 6: Effect of different treatments on total $\mathrm{Zn}$ uptake of two rice varieties.

\begin{tabular}{|c|c|c|c|}
\hline \multirow{2}{*}{ Treatments } & \multicolumn{3}{|c|}{ Total Zn uptake $\left(\mu \mathrm{g} \operatorname{pot}^{-1}\right)$} \\
\hline & PD16 & NDR359 & Mean \\
\hline Control & $1032.7^{\mathrm{a}}$ & $1045.7^{\mathrm{a}}$ & 1039.2 \\
\hline $2.5 \mathrm{mg} \mathrm{Zn} / \mathrm{kg}$ soil & $1574.3^{\mathrm{fg}}$ & $1180.7^{\mathrm{b}}$ & 1377.5 \\
\hline BC & $1220.0^{\mathrm{bc}}$ & $1417.3^{\mathrm{de}}$ & 1318.7 \\
\hline $\mathbf{A X}$ & $1228.3^{\mathrm{bc}}$ & $1146.7^{\mathrm{ab}}$ & 1187.5 \\
\hline $\mathbf{A B}$ & $1427.7^{\mathrm{de}}$ & $1212.7^{\mathrm{bc}}$ & 1320.2 \\
\hline $\mathbf{B C}+\mathbf{A X}$ & $1673.0^{\mathrm{g}}$ & $1496.0^{\mathrm{ef}}$ & 1584.5 \\
\hline $\mathbf{B C}+\mathbf{A B}$ & $1671.3^{\mathrm{g}}$ & $1420.7^{\mathrm{de}}$ & 1546.0 \\
\hline $\mathbf{A X}+\mathbf{A B}$ & $1354.0^{\mathrm{d}}$ & $1309.7^{\mathrm{cd}}$ & 1331.8 \\
\hline $\mathbf{B C}+\mathbf{A X}+\mathbf{A B}$ & $1605.7^{\mathrm{fg}}$ & $1350.3^{\mathrm{d}}$ & 1478.0 \\
\hline Mean & 1420.8 & 1286.6 & 1353.7 \\
\hline
\end{tabular}

Pair of treatments that are not significantly different from one another share the same letters checked by the Duncan's test at 5\% probability level. 


\subsection{Effect of bacterial inoculation on methionine concentration in grains}

Relatively higher methionine concentration was recorded in grains of NDR 359 as compared to PD 16 variety (Table 7).

The performance of different treatments averaged over the rice varieties indicated that all the treatments except $\mathrm{BC}$ significantly increased the methionine concentration in rice grains (Table 7 ). The highest methionine concentration was observed under the treatment $\mathrm{BC}+\mathrm{AX}+\mathrm{AB}$ and the magnitude of increase was 38.8 and $22.4 \%$ over the control and $\mathrm{Zn}$ fertilizer application, respectively.
The interaction effect of treatment $x$ variety significantly influenced the methionine concentration in grains (Table 7). In PD 16, methionine concentration in the grains was significantly increased under all the treatments except under treatment BC. Among all the treatments, the maximum methionine concentration in grains was recorded under the treatment $\mathrm{BC}+\mathrm{AX}+\mathrm{AB}$ which was 37.6 and $14.2 \%$ over the control and $\mathrm{Zn}$ fertilizer application, respectively. In NDR 359 also, the treatment $\mathrm{BC}+\mathrm{AX}+\mathrm{AB}$ maximally increased the concentration of methionine in the grains and the percent increase recorded was 40.7 and $29.4 \%$ over the control and $\mathrm{Zn}$ fertilizer application, respectively.

Table 7: Effect of different treatments on methionine and phytic acid concentration in grains of two rice varieties.

\begin{tabular}{|c|c|c|c|c|c|c|}
\hline \multirow{2}{*}{ Treatments } & \multicolumn{3}{|c|}{ Methionine concentration $\left(\mathrm{g} \mathrm{kg}^{-1}\right)$} & \multicolumn{3}{|c|}{ Phytic acid concentration $\left(\mathrm{g} \mathrm{kg}^{-1}\right)$} \\
\hline & PD16 & NDR359 & Mean & PD16 & NDR359 & Mean \\
\hline Control & $1.17^{\mathrm{a}}$ & $1.50^{\mathrm{e}}$ & 1.34 & $11.77^{\mathrm{ab}}$ & $17.73^{h}$ & 14.75 \\
\hline $2.5 \mathrm{mg} \mathrm{Zn/kg} \mathrm{soil}$ & $1.41^{\mathrm{d}}$ & $1.63^{\mathrm{g}}$ & 1.52 & $11.67^{\mathrm{a}}$ & $17.81^{\mathrm{h}}$ & 14.74 \\
\hline BC & $1.20^{\mathrm{ab}}$ & $1.51^{\mathrm{e}}$ & 1.36 & $12.03^{\mathrm{bc}}$ & $17.66^{\mathrm{h}}$ & 14.85 \\
\hline $\mathbf{A X}$ & $1.34^{\mathrm{c}}$ & $1.74^{\mathrm{h}}$ & 1.54 & $11.90^{\mathrm{ab}}$ & $17.76^{\mathrm{h}}$ & 14.83 \\
\hline $\mathbf{A B}$ & $1.46^{\mathrm{de}}$ & $1.50^{\mathrm{e}}$ & 1.48 & $12.59^{\mathrm{de}}$ & $17.80^{\mathrm{h}}$ & 15.20 \\
\hline $\mathrm{BC}+\mathrm{AX}$ & $1.26^{\mathrm{b}}$ & $1.52^{\mathrm{e}}$ & 1.39 & $11.79^{\mathrm{ab}}$ & $17.29^{\mathrm{g}}$ & 14.54 \\
\hline $\mathrm{BC}+\mathrm{AB}$ & $1.49^{\mathrm{e}}$ & $1.95^{\mathrm{i}}$ & 1.72 & $12.28^{\mathrm{cd}}$ & $17.60^{\mathrm{gh}}$ & 14.94 \\
\hline $\mathbf{A X}+\mathbf{A B}$ & $1.53^{\mathrm{ef}}$ & $1.59^{\mathrm{fg}}$ & 1.56 & $12.96^{\mathrm{f}}$ & $17.85^{\mathrm{h}}$ & 15.40 \\
\hline $\mathbf{B C}+\mathbf{A X}+\mathbf{A B}$ & $1.61^{\mathrm{g}}$ & $2.11^{\mathrm{j}}$ & 1.86 & $12.75^{\text {ef }}$ & $17.85^{\mathrm{h}}$ & 15.30 \\
\hline Mean & 1.39 & 1.67 & 1.53 & 12.19 & 17.71 & 14.9 \\
\hline
\end{tabular}

Pair of treatments that are not significantly different from one another share the same letters checked by the Duncan's test at $5 \%$ probability level. 
3.10. Effect of bacterial inoculation on phytic acid concentration in grains

The concentration of phytic acid in rice grains was significantly higher in NDR 359 as compared to PD 16 (Table 7).

The performance of different treatments averaged over the rice varieties indicated that none of the treatment was effective in significantly reducing the levels of phytic acid in rice grains (Table 7). However treatments $2.5 \mathrm{mg} \mathrm{Zn} \mathrm{kg}^{-1}$ soil and $\mathrm{BC}+\mathrm{AX}$ could maintain the level of phytic acid in grains as recorded under the control. On the other hand, increased phytic acid concentration was recorded in grains of plants received $A B$, $\mathrm{AX}+\mathrm{AB}$ and $\mathrm{BC}+\mathrm{AX}+\mathrm{AB}$ treatments. Rest all treatments could maintain the phytic acid level in grains similar to that of control.

The interaction effect of treatment $\times$ variety significantly influenced the concentration of phytic acid in grains (Table 7). In PD 16, all the treatments were ineffective in reducing the concentration of phytic acid in grains significantly. On the other hand, significantly higher phytic acid concentration was observed under the treatments $\mathrm{AB}, \mathrm{BC}+\mathrm{AB}, \mathrm{AX}+\mathrm{AB}$ and $\mathrm{BC}+\mathrm{AX}+\mathrm{AB}$ over the control. In NDR 359, only treatment $B C+A X$ significantly reduced the concentration of phytic acid in grains and the reduction observed was $2.5 \%$ as compared to control. Rest all treatments maintained the concentration of phytic acid in grains statistically similar to that of control.

\subsection{Effect of bacterial inoculation on Phytate to Zn ratio in rice grains}

In general, phytate: $\mathrm{Zn}$ ratio was lower in grains of PD 16 variety as compared to NDR 359 (Figure 1). The effect of different treatments averaged over rice varieties revealed that all the treatments except $\mathrm{BC}$ and $\mathrm{AX}$ significantly reduced the ratio of phytate: $\mathrm{Zn}$ in rice grains. A reduction of $38.4 \%$ was observed in this ratio under the bacterial inoculation $\mathrm{BC}+\mathrm{AX}$ as compared to control.

The interaction effect of treatments $\times$ variety significantly influenced the phytic acid: $\mathrm{Zn}$ ratio in rice grains. In PD 16 and NDR 359, phytate: $\mathrm{Zn}$ ratio was maximally reduced under the same treatment $\mathrm{BC}+\mathrm{AX}$; the magnitude of reduction was $33.3 \%$ in PD 16 while in NDR 359 it was $41.1 \%$ as compared to control.

\subsection{Effect of bacterial treatments on DTPA extractable Zn in soil after rice harvest}

In general, DTPA extractable Zn in soil after crop harvest was found higher under PD 16 variety as compared to NDR 359 variety (Table 8).

The effect of different treatments averaged over the rice varieties revealed significantly higher content of DTPA extractable $\mathrm{Zn}$ under treatments $2.5 \mathrm{mg} \mathrm{Zn} / \mathrm{kg}$ soil, $\mathrm{AX}$ and $\mathrm{BC}+\mathrm{AX}+\mathrm{AB}$ over the control.

The interaction effect of treatments $\times$ variety also significantly influenced the amount of DTPA extractable $\mathrm{Zn}$ in soil. In the case of PD 16 variety, the highest DTPA extractable $\mathrm{Zn}$ was observed under the treatment $A X$ and the increase was $31 \%$ over the control. The DTPA extractable $\mathrm{Zn}$ in soil after crop harvest under $2.5 \mathrm{mg} \mathrm{Zn} / \mathrm{kg}$ soil and $\mathrm{BC}+\mathrm{AX}+\mathrm{AB}$ treatments were statistically similar to the values recorded under treatment $A X$. In the case of NDR 359, the DTPA extractable $\mathrm{Zn}$ in soil was the highest under the treatments $\mathrm{BC}, \mathrm{AB}$ and $\mathrm{BC}+\mathrm{AX}+\mathrm{AB}$, the increase in DTPA extractable $\mathrm{Zn}$ in soil under these treatments was $10.84 \%$ compared to that of control pots. 
Table 8: Effect of bacterial treatments on DTPA extractable $\mathrm{Zn}$ in soil after rice harvest.

\begin{tabular}{cccc}
\hline & \multicolumn{3}{c}{ Available Zn $\left(\mathrm{mg} \mathrm{kg}^{-1}\right.$ soil) } \\
\cline { 2 - 4 } Treatments & PD16 & NDR359 & Mean \\
\hline Control & $0.85^{\mathrm{ab}}$ & $0.83^{\mathrm{a}}$ & 0.84 \\
$\mathbf{2 . 5} \mathbf{~ m g ~ Z n / k g ~ s o i l ~}$ & $1.30^{\mathrm{f}}$ & $0.88^{\mathrm{abc}}$ & 1.09 \\
$\mathbf{B C}$ & $1.10^{\mathrm{d}}$ & $0.92^{\mathrm{c}}$ & 1.01 \\
$\mathbf{A X}$ & $1.31^{\mathrm{f}}$ & $0.87^{\mathrm{abc}}$ & 1.09 \\
$\mathbf{A B}$ & $1.16^{\mathrm{de}}$ & $0.92^{\mathrm{c}}$ & 1.04 \\
$\mathbf{B C}+\mathbf{A X}$ & $1.20^{\mathrm{e}}$ & $0.89^{\mathrm{bc}}$ & 1.05 \\
$\mathbf{B C}+\mathbf{A B}$ & $1.12^{\mathrm{d}}$ & $0.87^{\mathrm{abc}}$ & 1.00 \\
$\mathbf{A X}+\mathbf{A B}$ & $1.20^{\mathrm{e}}$ & $0.88^{\mathrm{abc}}$ & 1.04 \\
$\mathbf{B C}+\mathbf{A X}+\mathbf{A B}$ & $1.26^{\mathrm{f}}$ & $0.92^{\mathrm{c}}$ & 1.09 \\
$\mathbf{M e a n}$ & 1.17 & 0.89 & 1.03 \\
\hline
\end{tabular}

Pair of treatments that are not significantly different from one another share the same letters checked by the Duncan's test at $5 \%$ probability level.

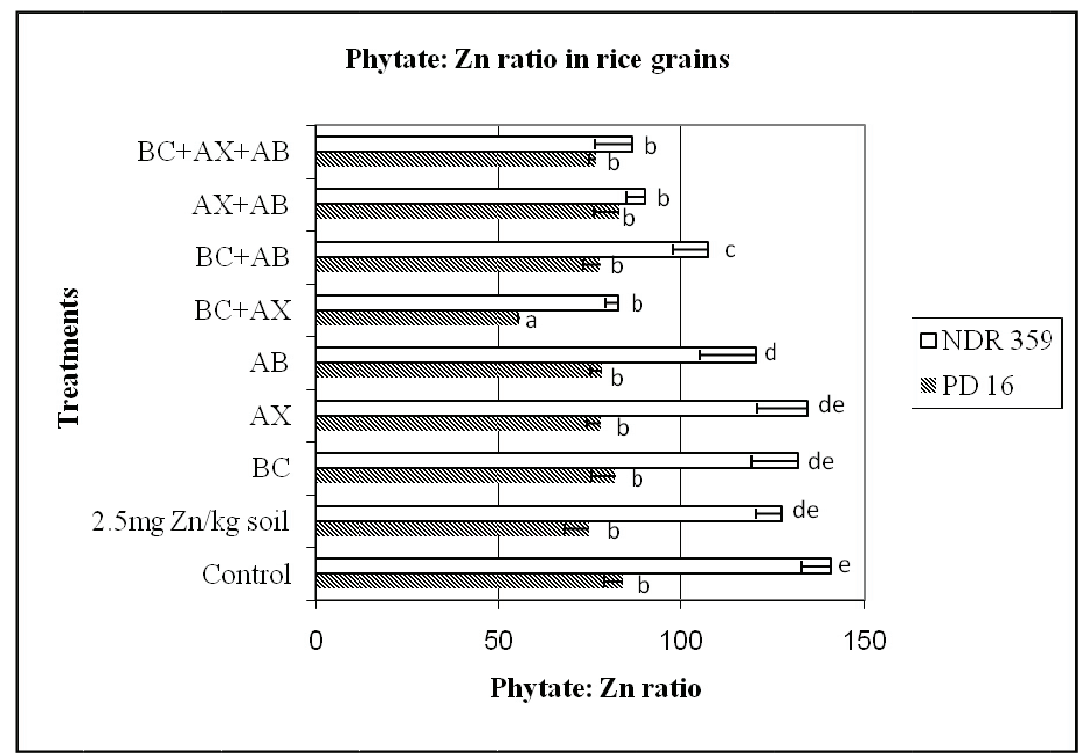

Figure 1. Effect of bacterial treatments on Phytate: $\mathrm{Zn}$ ratio in rice grains. Horizontal bars indicate LSD at $\leq 0.05$ 


\section{Discussion}

Pot culture screening experiments are very much essential for analyzing the effects of microbial bioinoculants on various plant growth parameters as well as on nutrient uptake before evaluating their efficacy under field conditions. In the present study, the effect of Burkholderia sp. SG1 (BC), Acinetobacter sp. SG2 (AX) and Acinetobacter sp. SG3 (AB) isolated from $\mathrm{Zn}$ deficient rice field on growth parameters and $\mathrm{Zn}$ nutrition of rice plants was examined in a pot culture experiment. In previous study, these three bacteria were characterized for $\mathrm{Zn}$ solubilization, siderophore, gluconic acid and IAA production (Vaid et al., 2013). Several workers have reported the beneficial effects of different strains of Burkholderia, Acinetobacter, Bacillus, Enterobacter, Alcaligenes, Arthrobacter, Azospirillium, Azotobacter, Beijerinckia, Erwinia, Flavobacterium, Rhizobium and Serratia and also identified them as prominent PGPR's (rodriguez and Fraga, 1999; Sturz and Norwak, 2000; Sahin et al., 2004; Malviya et al., 2012).

Bacterial strains $\mathrm{BC}, \mathrm{AX}$ and $\mathrm{AB}$ when used individually as well as in combination with each other improved growth and $\mathrm{Zn}$ uptake of plants significantly over the control as well as over $\mathrm{Zn}$ fertilizer treatment, respectively. The present experiment revealed that co-inoculation of rice seedlings (PD16 and NDR 359) with isolated Burkholderia and Acinetobacter strains significantly increased the dry matter yield pot ${ }^{1}$, number of productive tillers plant ${ }^{-1}$, number of panicles pot $^{-1}$ and number of grains panicle ${ }^{-1}$. In the present study, we found $15.1 \%$ increase in mean number of productive tillers per plant under bacterial treatments $\mathrm{BC}+\mathrm{AB}$ and $\mathrm{AX}+\mathrm{AB}$ over the control. Similar increase was reported earlier by Tran Van et al. (2000) who observed $13 \%$ more tillering in rice plants when inoculated with Burkholderia vietnamiensis TVV75. The increment recorded due to bacterial inoculations in mean dry matter yield pot ${ }^{-1}$ and mean number of grains panicle ${ }^{-1}$ was 12.9 and $12.8 \%$ respectively, over the control. These findings were concurrent with the results obtained by Tran Van et al. (2000) who recorded $11 \%$ more grains panicle ${ }^{-1}$ in rice plants inoculated with Burkholderia vietnamiensis TVV75 as compared to the non-inoculated ones. The results also showed significant increase in grain and straw yields due to bacterial inoculations. In experiments of Tariq et al. (2007), an increase of $65 \%$ in grain yield was observed due to inoculation with plant root associated PGPR in rice. Similar results were obtained by Minaxi et al. (2013) in wheat. They reported a remarkable $92.8 \%$ increase in seed yield when wheat plants were inoculated with a combination of Arbuscular mycorrhizal fungi and phosphate solubilizing bacteria.

The increase recorded in growth and yield attributes of two rice varieties could be attributed to higher mobilization of $\mathrm{Zn}$ by $\mathrm{Zn}$ solubilizing bacteria like Burkholderia sp. SG1, Acinetobacter sp. SG2 and Acinetobacter sp. SG3. These three bacterial cultures were isolated from $\mathrm{Zn}$ deficient rice field to ensure that they were already acclimatized to the conditions of rice field and this might be the reason for their good performance. Mader et al. (2011) also stated an increase of $23 \%$ in rice yield obtained by Jha et al. (2009) upon rice inoculation with a diazotropic ( $\mathrm{N}_{2}$-fixing) Pseudomonas sp. strain. From this statement, Mader et al. (2011) concluded that the increase obtained by Jha et al. (2009) was due to the appropriate selection 
of bioinoculants. Our bacterial isolates were also found positive for IAA production, a phytohormone responsible for increasing the length of the root hairs which could promote better absorption of nutrients from the soil. According to Volkmar and Bremer (1998) rapid establishment of roots including elongation of primary roots or proliferation of lateral/ adventitious roots is advantageous for young seedlings as it increases their ability to explore the soil to easily obtain water and nutrients. Nayak et al. (1986) reported that Azospirillum inoculation can increase height and number of tillers in rice plants. They mentioned that PGPR treatment increases chlorophyll content in plants and thereby enhances the rate of photosynthesis leading to improved overall plant health. Similar observations were reported by Mohite (2013) who showed that inoculation of wheat seedlings with rhizosphere soil isolates significantly increased the plant height, root length and chlorophyll content over the control.In our study we found bacterial inoculations more effective in enhancing the $\mathrm{Zn}$ concentration and its uptake in grains and straw of both of the rice varieties as compared to the application of $2.5 \mathrm{mg} \mathrm{Zn} \mathrm{kg}^{-1}$ soil. The poor performance of soil application of $2.5 \mathrm{mg} \mathrm{Zn}$ as zinc sulphate could be due to the tendency of $\mathrm{Zn}$ fertilizers to form insoluble complexes in the soil. According to Fageria et al. (1988) and Johnson-Beebout et al. (2009), P and $\mathrm{Zn}$ fertilizers can rapidly form insoluble complexes in the soil and remained unavailable for plant uptake unless genotypes with an improved capability to access these soil-bound nutrients are developed. Rose et al. (2012) also mentioned that $\mathrm{P}$ and $\mathrm{Zn}$ fertilizers are not always adequate to overcome the crop production constraints. They pointed out that fertilizers are costly inputs and their use limits the profitability of rice farming due to high-input or low-input systems. Zhu et al. (2007) stated that micronutrient fertilizers must be applied regularly and are, therefore, costly as well as potentially damaging to the environment. We have also observed that the DTPA extractable $\mathrm{Zn}$ content after rice harvest was significantly increased in soil under different bacterial treatments. The possible reason for this increase was the $\mathrm{Zn}$ solubilizing capabilities of the bacteria used in this experiment. After rice harvesting, the amount of DTPA extractable $\mathrm{Zn}$ was more in soil in which the plants of PD 16 variety were growing as compared to the soil in which plants of NDR 359 variety were growing. This might be due to the combined $\mathrm{Zn}$ solubilizing efforts of $\mathrm{Zn}$ solubilizing bacteria and the effect of plants of PD 16 variety on soil. We hypothesized that the exudates of PD16 variety were containing some organic acids and also in greater amounts that might be helpful in effecting higher solubilization of insoluble $\mathrm{Zn}$ present in the soil. This statement is in agreement with the statement of Widodo et al. (2010) who reported that $\mathrm{Zn}$ deficiency-tolerant rice line RIL46 acquired Zn more efficiently as compared to non-tolerant maternal line IR74 under field conditions. According to them this was due to increased root exudation of deoxymugineic acid (DMA) or low molecular weight organic acids and due to increased root production.

The results showed that due to bacterial inoculation $\mathrm{Zn}$ concentration in grains and straw was significantly increased both in PD 16 and NDR 359. The increase observed in mean $\mathrm{Zn}$ concentration in rice grains due to inoculation treatment was 56.9 and $49.5 \%$ over the control and $\mathrm{Zn}$ fertilizer application, respectively. This 
is in accordance with the findings of Tariq et al. (2007) who reported 157 and 9.7\% increase in $\mathrm{Zn}$ concentration in grains over the control and Chelated Zn-EDTA treatment respectively. Mader et al. (2011) also reported a substantial increase in $\mathrm{Mn}$ and $\mathrm{Zn}$ concentration in rice grains due to application of combination of natural mycorrhiza consortia and fluorescent Pseudomonas strain R62 + R81. Our results showed that all the bacterial inoculations caused significant increase in total $\mathrm{Zn}$ uptake per pot compared to non inoculated plants. This might be due to solubilization of insoluble soil $\mathrm{Zn}$ by production of gluconic acid by these isolates. Simine et al. (1998) reported the production of gluconic and 2 ketogluconic acid by strain of Pseudomonas fluorescens and found it responsible for $\mathrm{Zn}$ solubilization in broth assay. The overall increase in plant growth and nutrient uptake was the result of partly $\mathrm{Zn}$ solubilization and IAA production by the isolates. Fageria et al. (2002) found that the application of 120 $\mathrm{mg} \mathrm{Zn} \mathrm{kg}{ }^{-1}$ soil significantly improved the root growth of upland rice and wheat. Initiation and development of lateral roots, increase in root weight and nutrient uptake by PGPR inoculation were reported by Rolf et al. (1997) and Canbolat et al. (2006). In a green house experiment, Malik et al. (2002) observed an increase of $32-81 \%$ in rice yield due to Azospirillum inoculation. Nayak et al. (1986) reported that Azospirillum inoculation can increase height and number of tillers in rice plants. They mentioned that PGPR treatment increases chlorophyll content in plants and thereby enhances the rate of photosynthesis leading to improved overall plant health. Amino acids, such as methionine, histidine and organic acids (e.g., citrate) are known to have a positive effect on zinc absorption and have been used for zinc supplements (Lonnerdal, 2000). We analyzed methionine concentration in rice grains of both varieties and observed significant increase under different bacterial inoculations over the control. This could be due to better expression of RNA polymerase which needs $\mathrm{Zn}$ for its proper functioning. This fact is supported by the statement of Price (1962) who reported a sharp decline in RNA and number of ribosomes in Zn deficient cells. Marschner (1995) and Cakmak et al. (2010) also reported a positive correlation between grain $\mathrm{Zn}$ concentration and protein synthesis. Rice is an important staple food in Asian countries and in rural areas it is also a major source of micronutrients but unfortunately, the bioavailability of minerals, e.g. zinc from rice, is low because it is present as an insoluble complex with phytic acid (Liang et al., 2008). Phytic acid is actually the stored form of $\mathrm{P}$ in seeds or cereal grains. It has been well-documented that adequate $\mathrm{Zn}$ nutrition is important in controlling the uptake of $\mathrm{P}$ by roots (Marschner, 1995). Increasing the availability of $\mathrm{P}$ in the growth medium can induce $\mathrm{Zn}$ deficiency in plants by altering soil and plant factors (Robson and Pitman, 1983), but little is known about specific mechanisms. Huang et al. (2000) observed that Zn deficiency (low tissue $\mathrm{Zn}$ concentrations) caused an increase in the expression of $\mathrm{P}$ transporter genes in barley roots. They also reported that enhancing $\mathrm{P}$ uptake efficiency may cause a decrease in plant uptake of $\mathrm{Zn}$, leading to low $\mathrm{Zn}$ concentrations (densities) in food. According to Gianquinto et al. (2000) applications of large amounts of fertilizer $\mathrm{P}$ to soils that are low in available $\mathrm{Zn}$ can depress tissue $\mathrm{Zn}$ concentration or may even induce $\mathrm{Zn}$ deficiency. From the above statement we can conclude that $\mathrm{Zn}$ solubilizing bacteria 
solubilized $\mathrm{Zn}$ in soil \& made it available to the plants and as a result there will be no overexpression of $\mathrm{P}$ transporter genes in rice plants and hence no over accumulation of $\mathrm{P}$ in grains occurred in the present study and this might be the reason behind obtaining reduced phytate: $\mathrm{Zn}$ ratio under different bacterial treatments. In the present study, bacterial treatment $\mathrm{BC}+\mathrm{AX}$ produced maximum reduction in phytate: $\mathrm{Zn}$ ratio in grains of both of the rice varieties.

\section{Conclusion}

Thus, use of bacterial consortium such as Burkholderia sp. and Acinetobacter sp. can effectively increase the growth attributes and yield of rice. Rice plants inoculated with suitable combination of $\mathrm{Zn}$ solubilizing bacterial strains were found more efficient in acquiring $\mathrm{Zn}$ from Zn deficient soil as compared to non-inoculated plants. The findings indicated a possibility of reducing the cost incurred on $\mathrm{Zn}$ fertilizers in rice cultivation however, the verification of their effectiveness in augmenting $\mathrm{Zn}$ nutrition of rice under field condition is needed. Further validation of results under field conditions is in process. The present investigation also indicated the necessity of investigating the reasons of bacterial strain specificity in rice varieties of varying $\mathrm{Zn}$ responsiveness.

\section{Acknowledgement}

Authors are grateful for the financial support provided by NAIP, New Delhi.

\section{References}

Benton, D. 2008. Micronutrient status, cognition and behavioral problems in childhood. Eur. J. Nutr. 47, 38-50.

Black, R.E., Lindsay, H.A., Bhutta, Z.A., Caulfield, L.E., De Onnis M., Ezzati, M., Mathers, C., Rivera, J. 2008. Maternal and child under-nutrition: global and regional exposures and health consequences. Lancet. 371, 243-60.

Cakmak, I., Pfeiffer, W.H., McClafferty, B. 2010 Biofortification of durum wheat with zinc and iron. Cereal Chem. 87(1), 10-20.

Canbolat, M.Y., Bilen, S., Cakmakci, R., Ahin, S., Aydin, F. 2006. Effect of plant growth promoting bacteria and soil compaction on barley seedling growth, nutrient uptake, soil properties and rhizosphere microflora. Biol. Fertil. Soils. 42, 350-357.

Chaudhary, S.K., Thakur, S.K., Pandey, A.K. 2007. Response of wetland rice to nitrogen and Zinc. Oryza. 44(1), 44-47.

Fageria, N.K., Baligar, V.C., Clark, R.B. 2002. Micronutrients in crop production. Adv. Agron. 77, 185-268.

Fageria, N.K., Wright, R.J., Baligar, V.C. 1988. Rice cultivar evaluation for phosphorus use efficiency. Plant Soil. 111, 105-109.

Gianquinto, G., Abu-Rayyan, A., Tola, L.D., Piccotino, D., Pezzarossa, B. 2000. Interaction effects of phosphorus and zinc on photosynthesis, growth and yield of dwarf bean grown in two environments. Plant Soil. 220, 219-228.

Graham, R.D. 2008. Micronutrient deficiencies in crops and their global significance. In: B. J. Alloway (ed). Micronutrient deficiencies 
in global crop production. Springer, New York, pp: 41-61.

Gyaneshwar, P., Kumar, G.N., Parekh, L.J., Poole, P.S. 2002. Role of soil microorganisms in improving P nutrition of plants. Plant Soil. 245, 83-93.

Horn, M.J., Jones, D.B., Blum, A.E. 1946. Microbiological determination of methionine in proteins and foods. J. Biol. Chem. 166, 321-326.

Huang, C.Y., Barker, S.J., Langridge, P., Smith, F.W., Graham, R.D. 2000. Zinc deficiency up-regulates expression of high affinity phosphate transporter genes in both phosphate sufficient and deficient barley (Hordeum vulgare L. cv Weeah) roots. Plant Physiol. 124, 415-422.

Lindsay, W.L., Norvell. W.A. 1978. Development of a DTPA soil test for zinc, iron, manganese, and copper. Soil Sci. Soc. Am. J. 42, 421428.

Jha, B., Thakur, M.C., Gontia, I., Albrecht, V., Stoffels, M., Schmid, M., Hartmann, A. 2009. Isolation, partial identification and application of diazotrophic rhizobacteria from traditional Indian rice cultivars. Eur. J. Soil. Biol. 45, 62-72.

Johnson-Beebout, S.E., Lauren, J.G., Duxbury, J.M. 2009. Immobilization of zinc fertilizer in flooded soils monitored by adapted DTPA soil test. Comm. Soil. Sci. Plant Anal. 40, 1842-1861.

Latta, M., Eskin, M.A. 1980. Simple and rapid colorimetric method for phytate determination. J. Agric. Food Chem. 28, 1313-1315.

Liang, J., Han, Bei-Zhong., Nout, M.J.R., Hamer, R.J. 2008. Effect of soaking, germination and fermentation on phytic acid, total and in vitro soluble zinc brown rice. Food Chem. 110(4), 821-828.

Lonnerdal, Bo. 2000. Dietary factors influencing zinc absorption. International workshop "Zinc and Health: Current Status and Future directions". J. Nutr. 130(5), 1378S-1383S.

Lott, J.N.A. 1984. Accumulation of seed reserves of phosphorus and other minerals. In: D.R. Murray, (ed). Seed Physiology, Academic Press, New York, pp: 139-166.

Lugtenberg, B., Kamilova, F. 2009. PlantGrowth-Promoting Rhizobacteria. Annu. Rev. Microbiol. 63, 541-556.

Mäder, P., Kaiser, F., Adholeya, A., Singh, R., Uppal, H.S., Sharma, A.K., Srivastava, R., Sahai, V., Aragno, M., Wiemken, A., Johri, B.N., Fried, P.M. 2011. Inoculation of root microorganisms for sustainable wheat rice and wheat black gram rotations in India. Soil. Biol. Biochem. 43, 609-619.

Malik, K.A., Mirza, M.S., Hassan, U., Mehnaz, S., Rasul, G., Haurat, J., Bally, R., Normand, P. 2002. The role of plant-associated beneficial bacteria in rice-wheat cropping system. In: I. R. Kennedy, A.T.M.A.Choudhury (eds). Biofertilizers in Action. Rural Industries Research and Development Corporation, Canberra, ACT, Australia, pp: 73-83.

Malviya, M.K., Sharma, A., Pandey, A., Rinu, K., Sati, P., Palni, L.M.S. 2012. Bacillus subtilis NRRL B-30408: A potential inoculant for crops grown under rainfed conditions in the mountains. J. Soil Sci. Plant Nutr. 12(4), 811-824.

Marschner, H. 1995. Mineral nutrition of higher plants. Second Edition, Academic press, London.

Minaxi., Saxena, J., Chandra, S., Nain, L. 2013. Synergistic effects of phosphate solubilizing rhizobacteria and arbuscular mycorrhizal 
fungi on growth and yield of wheat plants. J. Soil Sci. Plant Nutr. 13(2), 511-525.

Mohite, B. 2013. Isolation and characterization of indole acetic acid (IAA) producing bacteria from rhizospheric soil and its effect on plant growth. J. Soil Sci. Plant Nutr. 13(3), 638-649.

Nayak, D.N., Ladha, J.K., Watanabe, I. 1986. The fate of marker Azospirillum lipoferum inoculated into rice and its effect on growth, yield and $\mathrm{N}_{2}$ fixation of plants studied by acetylene reduction, ${ }^{15} \mathrm{~N}_{2}$ feeding and ${ }^{15} \mathrm{~N}$ dilution techniques. Biol. Fertil. Soils. 2, 7-14.

Neue, H.U., Lantin, R.S. 1994. Micronutrient toxicities and deficiencies in rice. In: A.R Yeo, T.J Flowers. (eds). Soil Mineral Stresses, Approaches to Crop Improvement. Springer-Verlag, Berlin, pp: 175-200.

Ogut, M., Fatih, Er., Kandemir, N. 2010. Phosphate solubilization potentials of soil Acinetobacter strains. Biol. Fert. Soils. 46, 707-715.

Perrott, K.W., Sarathchandra, S.U., Dow, B.W. 1992. Seasonal and fertilizer effects on the organic cycle and microbial biomass in a hill country soil under pasture. Aust. J. Soil Res. 30, 383-394.

Price, C.A. 1962. RNA synthesis, zinc deficiency and the kinetics of growth. J. Plant Physiol. 37, XXI.

Rhou, J.R., Erdman, J.V. 1995. Phytic acid in health and disease. Crc. Cr. Rev. Food Sci. 35, 495-508.

Robson, A.D., Pitman, M.G. 1983. Interactions between nutrients in higher plants. In: Lauchli, A., Bieleski, R.L. eds. Encyclopedia of plant physiology. Vol 15A. New series, Berlin and New York: Springer-Verlag, 287312.
Rodriguez, H., Fraga, R. 1999. Phosphate solubilizing bacteria and their role in plant growth promotion. Bio. Technol. Adv. 17, 319-339.

Rose, T.J., Impa, S.M., Rose, M.T., Tanaka, J.P., Mori, A., Heuer, S., Johnson-Beebout S.E, Wissuwa, M. 2012. Enhancing phosphorus and zinc acquisition efficiency in rice: a critical review of root traits and their potential utility in rice breeding. Ann. Bot. 1-15.

Sahin, F., Cakmakci, R., Kantar, F. 2004. Sugar beet and barley yields in relation to inoculation with $\mathrm{N}_{2}$-fixing and phosphate solubilizing bacteria. Plant Soil. 265, 123129.

Srivastava, P.C., Gangwar, M.S. 1990. Critical limits of zinc in mollisols and rice plant parts for predicting response of rice to zinc application. Oryza. 27, 291-295.

Sharma, A., Shankhdhar, D., Sharma, A., Shankhdhar, S.C. 2014. Growth promotion of rice genotypes by pgprs isolated from rice rhizospheres. J. Soil Sci. Plant Nutr. 14(2), 505-517.

Shewry, P.R. 2006. Improving the protein content and quality of temperate cereals: Wheat, Barley and Rye, in Impacts of Agriculture on Human Health and Nutrition, [Eds. Ross M. Welch, and Ismail Çakmak], in Encyclopedia of Life Support Systems (EOLSS), Developed under the Auspices of the UNESCO, Eolss Publishers, Oxford ,UK, [http://www.eolss.net]

Simine C.D. Di., Sayer, J.A., Gadd, G.M. 1998. Solubilization of Zinc phosphate by a strain of Pseudomonas fluorescence isolated from a forest soil. Biol. Fertil. Soils. 28, 87-94.

Singh, M.V. 2009. Evaluation of current micronutrient stocks in different Agro- 
Ecological zones of India for sustainable crop production. Fert. News. 46, 25-42.

Snedecor GW, Cochran WG (1967) Statistical Methods, Sixth Edition, The Iowa state university Press, Ames.

Steinshamn, H., Thuen, E., Bleken, M.A., Brenoe U.T., Ekerholt, G., Yri, C. 2004. Utilization of nitrogen and $\mathrm{P}$ in an organic dairy farming system in Norway. Agric. Ecosyst. Environ. 104, 509-522.

Sturz, A.V., Nowak, J. 2000. Endophytic communities of rhizobacteria and the strategies required to create yield enhancing associations with crops. Appl. Soil Ecol. 15, 183-190.

Tapiero, H., Tew, K.D. 2003. Trace elements in human physiology and pathology: zinc and metallothioneins. Biomed. Pharmacother. 57(9), 399-411.

Tariq, M., Hameed, S., Malik, K.A., Hafeez, F.Y. 2007. Plant root associated bacteria for zinc mobilization in rice. Pak. J. Bot. 39(1), 245253.

Tilak, K.V.B.R., Singh, C.S., Roy, N.K., Subba Rao, N.S. 1982. Azospirillum brasilense and Azotobacter chroococcum inoculums: Effect on yield of maize (Zea mays) and sorghum (Sorghum bicolor). Soil. Biol. Biochem. 14, 417-418.

Tilman, D. 1998. The greening of the green revolution. Nature. 396, 211-212.

Trân Van, V., Berge, O., Ngô, Kê. S., Balandreau, J., Heulin, T. 2000. Repeated beneficial effects of rice inoculation with a strain of Burkholderia vietnamiensis on early and late yield components in low fertility sulphate acid soils of Vietnam. Plant Soil. 218, 273284.
Vaid, S.K., Gangwar, B.K., Sharma, A., Srivastava, P.C., Singh, M.V. 2013. Effect of zinc solubilizing bioinoculants on zinc nutrition of wheat (Triticum aestivum L.). Int. J. Adv. Res. 1(9), 805-820.

Van Breemen N., Castro, R.U. 1980. Zinc deficiency in wetland rice along a toposequence of hydromorphic soils in the Philippines. II. Cropping experiment. Plant Soil. 57, 215-221.

Volkmar, K.M., Bremer, E. 1998. Effect of seed inoculation with a strain of Pseudomonas fluorescens on root growth and activity of wheat in well-watered and drought-stressed glass-fronted rhizotrons. Can. J. Plant Sci. $78,545-551$.

WHO. 2002 The World Health Report- Reducing risks, promoting healthy life. Geneva, pp 168.

Widodo, B.M.R., Rose, T., Frei M . 2010. Response to zinc deficiency of two rice lines with contrasting tolerance is determined by root growth maintenance and organic acid exudation rates, and not by zinc-transporter activity. New Phytologist. 186, 400-414.

Wissuwa, M., Ismail, A.M., Yanagihara, S. 2006. Effects of Zinc Deficiency on Rice Growth and Genetic Factors Contributing to Tolerance. J. Plant Physiol. 142, 731-741.

Yoshida, S., Tanaka, A. 1969. Zinc deficiency of the rice plant in calcareous soils. Soil Sci. Plant Nutr. 15, 75-80.

Zhu, C., Naqvi, S., Gomez-Galera, S., Pelacho, A.M., Capell, T., Christou, P. 2007. Transgenic strategies for the nutritional enhancement of plants. Trends in Plant Sci. $12,548-555$. 